\title{
PROTEOMIC INSIGHT INTO THE PRIMYCIN FERMENTATION PROCESS OF SACCHAROMONOSPORA AZUREA
}

\author{
Andrea Valasek, ${ }^{1}$ Írisz Éva Kiss, ${ }^{1,2}$ IstVán Fodor,,${ }^{1,2}$ Márk Kovács, ${ }^{1,2}$ \\ Péter Urbán, ${ }^{1,2}$ Éva JÁmbor, ${ }^{3}$ Csaba Fekete ${ }^{1,2}$ and Ildikó Kerepesi ${ }^{2 *}$ \\ ${ }^{1}$ Szentágothai Research Centre, University of Pécs, Pécs, Hungary \\ 2Department of General and Environmental Microbiology, University of Pécs, Pécs, Hungary \\ ${ }^{3}$ Department of Biochemistry and Medical Chemistry, University of Pécs, Pécs, Hungary
}

(Received: February 15, 2016; accepted: May 4, 2016)

\begin{abstract}
Saccharomonospora azurea SZMC 14600 is a member of the family Pseudonocardiaceae exclusively used for industrial scale production of primycin a large 36-membered non-polyene macrolide lactone antibiotic belonging to the polyketide class of natural products. Even though maximum antibiotic yield has been achieved by empirically optimized two-step fermentation process, little is known about the molecular components and mechanisms underlying the efficient antibiotic production. In order to identify differentially expressed proteins (DEPs) between the pre- and main-fermentation stages of primycin, comparative 2D-PAGE experiments were performed. In total, 98 DEP spots were reproducibly detected, out of which four spots were excised from gels, and identified through MALDI-TOF/TOF mass spectrometry. Peptide mass fingerprint analysis revealed peptide matches to HicB antitoxin for the HicAB toxinantitoxin system (EHK86651), to a nucleoside diphosphate kinase regulator ((Ndk; EHK81899) and two other proteins with unknown function (EHK88946 and EHK86777).
\end{abstract}

Keywords: Differentially expressed proteins - HicB-family protein - primycin - Saccharomonospora azurea - two-dimensional protein gel electrophoresis

\section{INTRODUCTION}

As the problem of antimicrobial resistance becomes more widespread, the need for new anti-infective agents is more urgent than ever [20]. Actinomycetes are known as one of the most significant producers of pharmacologically important metabolites with over 10,000 bioactive compounds identified $[1,15]$. Our previous study demonstrated that Saccharomonospora azurea SZMC 14600 strain has an enhanced ability to produce primycin, a non-polyene macrolide lactone antibiotic [11). This heat stable, organic solvent soluble antibiotic complex (A1, A2 and C1) was first described by Vályi-Nagy et al. [18]. Primycin (primycin sulphate) is an active ingredient of Ebrimycin gel that has been successfully applied to prevent the bacterial infection of surface traumas and burned tissues. Comparative in vitro re-investigation of the efficacy of primycin clearly demonstrated that the antibiotic possesses high activity against the most frequent Gram-positive pathogens including some multi-drug resist-

*Corresponding author; e-mail address: ilda@gamma.ttk.pte.hu 
ant strains, without remarkable resistance development [8]. To get a deeper insight into the bioactive natural products metabolism of S. azurea SZMC 14600 wholegenome sequencing was performed [5]. The genome project clearly demonstrated that $S$. azurea is a prolific source of structurally diverse secondary metabolites, however, the in silico information was not tied to products in the laboratory until now. In order to further support our structural genomic data, in this pilot study a proteomics approach was performed. Two-dimensional protein gel electrophoresis (2-DE) followed by MALDI-TOF mass spectrometry supported by bioinformatics tools allowed in-depth-analysis for understanding complex biological process of microbial secondary metabolism [4]. Our preliminary comparative proteomic study of S. azurea cultivated sequentially in pre- and main-fermentation medium revealed considerable quantitative and qualitative differences in protein profiles. Among the differentially expressed and clearly detectable proteins a nucleoside diphosphate kinase regulator, one of the HicB-family proteins, and two proteins with unknown functions were identified.

\section{MATERIALS AND METHODS}

Saccharomonospora azurea SZMC 14600 freeze-dried stock cultures maintained at $-80{ }^{\circ} \mathrm{C}$ in Luria broth (Sigma-Aldrich) with $20 \%$ glycerol were used to directly inoculate $50 \mathrm{~mL}$ of pre-fermentation medium (PF) containing 3\% (w/v) soy flour; $4.2 \%(\mathrm{w} / \mathrm{v})$ water soluble starch; $0.36 \%(\mathrm{w} / \mathrm{v}) \mathrm{NaCl} ; 0.6 \%(\mathrm{w} / \mathrm{v}) \mathrm{CaCO}_{3}$ and $0.5 \%$ $(\mathrm{w} / \mathrm{v})$ sun oil $(\mathrm{pH} 8)$. PF-culture was grown for 2 days at $37^{\circ} \mathrm{C}$ in an orbital shaker at $200 \mathrm{rpm}$. Thereafter $1 \mathrm{~mL}$ suspension of bacterial cells was used to inoculate $35 \mathrm{~mL}$ of main-fermentation medium (MF) containing 4\% (w/v) soy flour; $4 \%(\mathrm{w} / \mathrm{v})$ water soluble starch; $0.3 \%(\mathrm{w} / \mathrm{v}) \mathrm{NaCl} ; 0.5 \%(\mathrm{w} / \mathrm{v}) \mathrm{CaCO}_{3} ; 0.6 \%(\mathrm{w} / \mathrm{v})$ sun oil; $0.3 \%(\mathrm{w} / \mathrm{v})$ stearic acid and $0.1 \%(\mathrm{w} / \mathrm{v}) \mathrm{KH}_{2} \mathrm{PO}_{4}(\mathrm{pH} 9.5)$. The submerged MF cultures were incubated for 5 days on a rotary shaker $(200 \mathrm{rpm})$ at $28^{\circ} \mathrm{C}$.

Soluble proteins were extracted from $300 \mathrm{mg}$ fresh weight of mycelia mats as described by Wang et al. [19]. Upon completion of the first dimension, samples containing $250 \mu \mathrm{g}$ of total protein were mixed with rehydration buffer. Isoelectric focusing of rehydrated protein samples were performed on $7 \mathrm{~cm}$ IPG Strips (pH 3-11, Bio-Rad) at $250 \mathrm{~V}$ for $15 \mathrm{~min}$ (rapid voltage ramping), at $4000 \mathrm{~V}$ for 1 hour (linear voltage ramping), at $4000 \mathrm{~V}$ for 15 hours (rapid voltage ramping). Finally, in order to avoid potential artefacts and to prevent diffusion of focused proteins, a hold step was maintained at $500 \mathrm{~V}$ until the run was stopped. After focusing, the IPG strips were equilibrated in $6 \mathrm{M}$ urea; $20 \%(\mathrm{v} / \mathrm{v})$ glycerol; $2 \%(\mathrm{w} / \mathrm{v}) \mathrm{SDS} ; 0.05 \mathrm{M}$ Tris- $\mathrm{HCl}(\mathrm{pH}$ 8.8 ), and $2 \%(\mathrm{w} / \mathrm{v})$ DTT for $20 \mathrm{~min}$. The second dimension protein separations were performed on $12.5 \%(\mathrm{w} / \mathrm{v})$ sodium dodecyl sulphate-polyacrylamide (SDS-PAGE) gels, stained with Coomassie Brilliant Blue (Sigma-Aldrich). Gel images were captured by AlphaImager high performance gel documentation system (Protein Simple, Alpha Innotech Co. San Leandro, CA) and protein spots were quantified using Prodigy SameSpots 2D software-package (Xpedition version 1.0, Alpha Innotech) 
according to the manufacturer's instructions. The normalized volume intensity was used for comparison between groups. The spots whose normalized volume intensity was higher than 1.5 and lower than 0.5 with respect to the control (LB or EF) at the level of $p<0,05$ were defined as differential expressed protein (DEP). Three independent biological replicates were performed under each condition (cultivation on $\mathrm{LB}, \mathrm{EF}$ and $\mathrm{MF}$ ).

Four of the differentially expressed protein spots were excised from the gel and destained by washing three times for $10 \mathrm{~min}$ in $200 \mu \mathrm{L}$ of $50 \%(\mathrm{v} / \mathrm{v})$ acetonitrile solution containing $50 \mathrm{mM} \mathrm{NH}_{4} \mathrm{HCO}_{3}$. The disulphide bonds of cysteines were reduced by $50 \mu \mathrm{L}$ of $20 \mathrm{mM}$ dithiotreitol (DTT) in $100 \mathrm{mM} \mathrm{NH}_{4} \mathrm{HCO}_{3}$ for $1 \mathrm{~h}$ at $55^{\circ} \mathrm{C}$. The alkylation of the cysteine groups was carried out in $50 \mu \mathrm{L}$ of $20 \mathrm{mM}$ iodoacetamide solution. The gel pieces were dehydrated at room temperature by a Speed Vac Concentrator (Speed Vac Plus, SC100A, Savant) and proteins were in-gel-digested in $10 \mu \mathrm{L}$ of $40 \mu \mathrm{g} / \mu \mathrm{L}$ modified trypsin (Promega, Madison, WI) in Tris buffer $(2.5 \mathrm{mM}$, $\mathrm{pH} 8.5$ ) at $37{ }^{\circ} \mathrm{C}$ overnight [16]. The digestion reactions were stopped with $15 \mu \mathrm{L}$ aqueous solution of acetonitrile and formic acid (49/50/1 v/v/v).

Protein samples were analysed using a MALDI TOF/TOF MS (Bruker Daltonics). Proteins from MS/MS spectra were identified using ProteinScape 2.1 server utilizes the MASCOT PMF database search software (www.matrixscience.com., Matrix Science Ltd.) and Bruker BioTools 3.2 software (Bruker Daltonics) accessing the MSDB, Swiss-Prot and NCBI non-redundant protein databases. The search parameters were set as follows. Two missed cleavages were allowed; carbamidomethyl was set as fixed and oxidized methionine as variable modification, monoisotopic peptide masses was set to $150 \mathrm{ppm}$. In parallel, to improve the coverage and confidence of identified peptides open reading frame database of S. azurea SZMC14600 was also applied. Virtual protein patterns corresponding to the genomic data were generated by JVirGel 2.0 software [10]. All experiments were performed in triplicate.

\section{RESULTS}

Proteomics techniques based on two-dimensional gel electrophoresis are capable of simultaneously separating thousands of proteins from a single organism. Our comparative whole genome analysis of $S$. azurea SZMC14600 revealed 4554 potential protein coding genes, among them 209 (4.5\%) were considered involved in the regulation of secondary metabolism, transport and metabolic processes (unpublished data). The comparison of the protein profiles of $S$. azurea cells obtained from the sequential culturing process in LB, PF and MF media revealed on average $402 \pm 23$, $422 \pm 31$ and $424 \pm 33$ detectable protein spots, respectively (Fig. 1). The finding that a vast majority of proteins were separated in the molecular mass range of $10-88 \mathrm{kDa}$ and had a pI range of 4.0-7.0 is in good agreement with previously published data $[17,21]$. Among the visualized proteins $77 \pm 12 \%$ were consistently present on all gels, nevertheless changing culture media from LB to PF and subsequently from PF to MF revealed 39 and 43 newly appeared (up-regulated) protein spots, respectively 


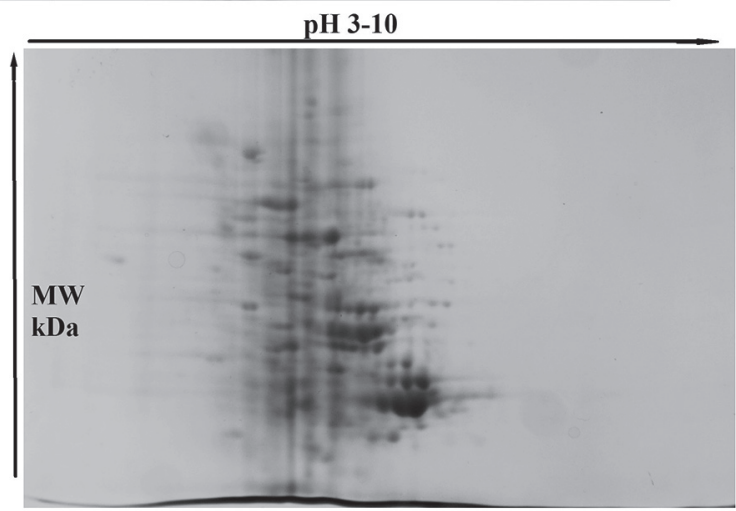

A

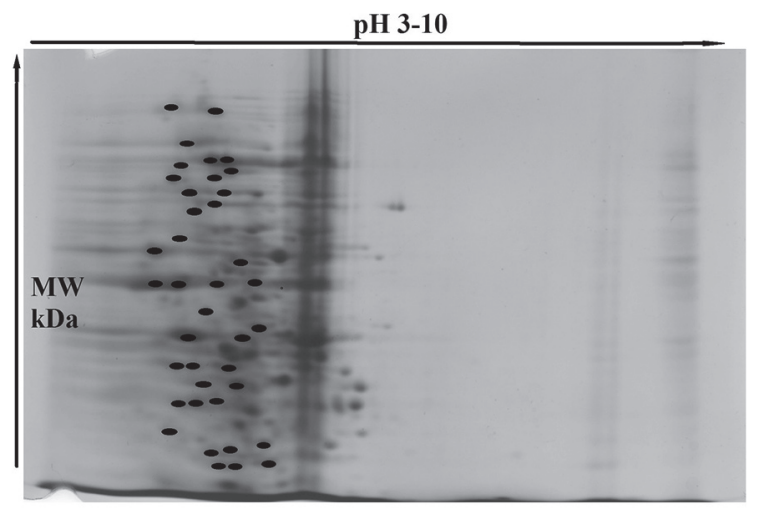

B

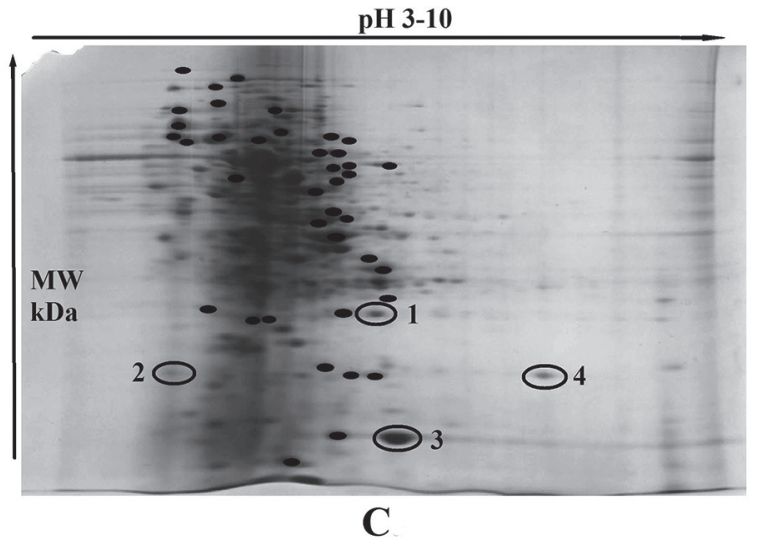

Fig. 1. Two-dimensional gel electrophoresis images of the total proteins from high primycin producer $S$. azurea SZMC 14,600 grown in: A) LB medium, B) Pre-fermentation medium (PF), C) Main-fermentation medium (MF). The presence of newly appeared protein spots, which were detectable in all gels are indicated by small black dots $(B, C)$. Individual peptide spots $(C)$ are numbered accordingly: 1 . HicB-family protein; 2. Nucleoside diphosphate kinase regulator; 3. and 4., unknown proteins 
Table 1

List of the identified proteins corresponding to excised spots from 2-DE by MALDI TOF/TOF MS system

\begin{tabular}{|c|l|c|c|c|c|c|}
\hline $\begin{array}{c}\text { Spot' } \\
\text { number }\end{array}$ & \multicolumn{1}{|c|}{ Identified protein } & Protein ID & Score & $\begin{array}{c}\text { Calculated } \\
\text { MW (Da) pI }\end{array}$ & $\begin{array}{c}\text { Fold change } \\
\text { MF/PF }\end{array}$ & $\begin{array}{c}\text { P } \\
\text { value }\end{array}$ \\
\hline 1 & HicB-family protein & EHK86651 & 107 & $19158-6.54$ & $11.5 \pm 2.3$ & 0.009 \\
\hline 2 & $\begin{array}{l}\text { Nucleoside } \\
\text { diphosphate kinase } \\
\text { regulator }\end{array}$ & EHK81899 & 46 & $16000-5.13$ & $6.3 \pm 1.1$ & 0.036 \\
\hline 3 & Unknown protein & EHK88946 & 70 & $15933-6.80$ & $13.8 \pm 0.8$ & $<0.001$ \\
\hline 4 & Unknown protein & EHK86777 & 106 & $18065-8.19$ & $14.3 \pm 0.7$ & $<0.001$ \\
\hline
\end{tabular}

(Fig. 1B, C). In this pilot study, four of the MF medium induced peptide spots (Fig. 1C), that may be involved in enhancing the production of primycin were excised and analysed using MALDI TOF mass spectrometry. The corresponding single charged monoisotopic peptide masses were searched against MSDB, Swiss-Prot and NCBInr databases and revealed significant homology with one of the HicB family proteins, a nucleoside diphosphate kinase (Ndk) regulator and two other unknown proteins (Table 1). The most exciting and unexpected finding was the appearance of a HicB protein (antitoxin for the HicAB toxin-antitoxin system) in parallel with the enhanced primycin synthesis during the second phase of fermentation process.

\section{DISCUSSION}

It is widely accepted that bacterial secondary metabolism usually starts in the stationary phase of cell growth (idiophase) when cells encounter adverse environmental conditions, as represented by depletion of essential nutrients or the presence of different stress stimuli. Genomics-based technologies, including whole genome sequencing, transcriptome, proteome, and metabolome profiling, together with in silico modelling and simulation, have become vital tools in the recently evolved industrial system biology [13].

Since the first description of plasmid encoded bacterial toxin-antitoxin (TA) systems [14], several chromosomally located TA systems have been studied, however, their biological functions are still under debate $[6,12]$. Chromosomal TA systems are small genetic modules classified into five types depending on the nature and mode of action of the antitoxin [9]. Although type II TA systems are probably the most abundant and the best described class of TA systems, little is known about the roles of Hic AB protein homologs of Gram-positive bacteria [2, 7]. In type II class, the antitoxin is a small protein capable of blocking the toxin's disruptive behaviour by direct protein binding or blocking the promoter region of the TA operon. Our finding that HicB antitoxin was detected exclusively in late stage of the antibiotic fermentation 
process underscore the hypothesis that TA systems could play a role in secondary metabolite production activated by nutrient starvation or other forms of environmental stresses.

Additionally, three differential protein spots were found related to the main-fermentation step (Table 1). Spots 3 and 4 (Fig. 1B) represent predicted proteins with unknown functions, while the spot 2 corresponds with the nucleoside diphosphate kinase regulator protein. $\mathrm{Ndk}$ is a major housekeeping enzyme in the production of NTPs and dNTPs that are fundamental for DNA/RNA synthesis, cell division, macromolecular metabolism and growth, thus Ndk is important in the regulation of stationary phase survival of the bacterial cells [3].

Taken together, according to our best knowledge, this is the first report which offers proteomic insight into the primycin fermentation process of $S$. azurea SZMC 14600.

As a first step to create an optimal workflow for large-scale experiments, methods of high-resolution protein separation and parameters for peptide mass fingerprinting identifies proteins were optimized. Our pilot study based on SDS-PAGE followed by MALDI-TOF mass spectrometry revealed significant differences in protein profiles between the two stages of primycin fermentation process, however, further studies are required to clarify the potential role of these proteins.

\section{ACKNOWLEDGEMENT}

The present scientific contribution is dedicated to the $650^{\text {th }}$ anniversary of the foundation of University of Pécs, Hungary.

\section{REFERENCES}

1. Bérdy, J. (2005) Bioactive microbial metabolites. J. Antibiot. 58, 1-26.

2. Butt, A., Higman, V. A., Williams, C., Crump, M. P., Hemsley, C. M., Harmer, N., Titball, R. W. (2014) The HicA toxin from Bulkholderia pseudomallei has role in persister cell formation. Biochem. J. 459, 333-344.

3. Chakrabarty, A. M. (1998) Nucleoside diphosphate kinase: role inbacterial growth, virulence, cell signalling and polysaccharide synthesis. Mol. Microbiol. 8, 875-882.

4. Chaudhary, A. K., Dhakal, D., Sohng, J. K. (2013) An insight into the "omics" based engineering of Streptomycetes for secondary metabolite overproduction. Biomed. Res. Int. doi:10.1155/2013/968518

5. Csepregi, K., Valasek, A., Pénzes, Á., Tóth, Zs., Kiss, É. I., Kerepesi, I., Horváth, B., Nagy, I., Fekete, Cs. (2012) Draft genome sequence of an efficient antibiotic-producing industrial strain of Saccharomonospora azurea, SZMC 14600. J. Bacteriol. 194, 1263.

6. De Bast, M. S., Mine, N., Van Melderen, L. (2008) Chromosomal toxin-antitoxin systems may act as antiaddiction modules. J. Bacteriol. 190, 4603-4609.

7. Durand, S., Jahn, N., Condon, C., Brant, S. (2012) Type I. toxin-antitoxin systems in Bacillus subtilis. RNA Biol. 9, 1491-1497.

8. Feiszt, P., Mestyán, Gy., Kerényi, M., Dobay, O., Szabó, J., Dombrádi, Zs., Urbán, E., Emődy, L. (2014) Re-evaluation of in vitro activity of primycin against prevalent multiresistent bacteria. Int. $J$. Med. Microbiol. 304, 1077-1085.

9. Goeders, N., Van Melderen, L. (2014) Toxin-antitoxin systems as multilevel interaction systems. Toxins (Basel) 6, 304-324. 
10. Hiller, K., Grote, A., Maneck, M., Münch, R., Jahn, D. (2006) JVirGel 2.0: computational prediction of proteomes separated via two-dimensional gel electrophoresis. Bioinformatics 22, 2441-2443.

11. Juhász, Á., Pénzes, Á., Péteri, Z., Pallos, J. P., Seffer, V., Feiszt, P., Pesti, M., Fekete, Cs., Vágvölgyi, Cs., Gazdag, Z., Papp, G. Process for producing primycin, primycin component(s), precursors and metabolites thereof via fermentation by the use of bacterial species Saccharomonospora azurea. 5 May 2011, WIPO patent application WO/2011/051741

12. Magnuson, R. D. (2007) Hypothetical functions of toxin-antitoxin systems. J. Bacteriol. 189, 60896092.

13. Otero, J. M., Nielsen, J. (2010) Industrial systems biology. Biotechnol. Bioeng. 15, 439-460.

14. Ogura, T., Hiraga, S. (1983) Mini-F plasmid genes that couple host cell division to plasmid proliferation. Proc. Natl Acad. Sci. USA. 80, 4784-4788.

15. Raja, A., Prabakaran, P. (2011) Actinomycetes and drug-an overview. Am. J. Drug Discov. Dev. 1, 75-84.

16. Shevchenko, A., Tomas, H., Havlis, J., Olsen, J.V., Mann, M. (2006) In-gel digestion for mass spectrometric characterization of proteins and proteomes. Nat. Protoc. 6, 2856-2860.

17. Yang, Q., Ding, X., Liu, X., Liu, S., Sun, J., Yu, Z., Hu, S., Rang, J., He, H., He, L., Xia, L. (2014) Differential proteomic profiling reveals regulatory proteins and novel links between primary metabolism and spinosad production in Saccharopolyspora spinosa. Microb. Cell Fact. 13:e27 doi: $10.1186 / 1475-2859-13-27$

18. Vályi-Nagy, T., Úri, J., Szilágyi, I. (1954) Primycin, a new antibiotic. Nature 174, 1105-1106.

19. Wang, W., Vignani, R., Scali, M., Cresti, M. (2006) A universal and rapid protocol for protein extraction from recalcitrant plant tissues for proteomic analysis. Electrophoresis 27, 2782-2786.

20. World Health Organization (WHO) Antimicrobial Resistance Global Report on surveillance (2014)

21. Wongtrakoongate, P., Mongkoldhumrongkul, N., Kamchonwongpaisan, S. K., Tungpradabkul, S. (2007) Compatative proteomic profiles and potential markers between Bulkholderia pseudomallei and Bulkholderia thailandensis. Mol. Cell. Probes 21, 81-91. 